\title{
Pricing of Digital Innovations as an Entrepreneurial Process
}

\author{
Arto Ojala \\ University of Jyväskylä \\ arto.k.ojala@jyu.fi
}

\author{
Gabriella Laatikainen \\ University of Jyväskylä \\ gabriella.g.laatikainen@jyu.fi
}

\begin{abstract}
How do entrepreneurs set a price for digital innovations they develop and market? This is an important question in current information society where digitalization is making established pricing models outdated. In this study, we focus on this issue by examining what kinds of activities and resources entrepreneurs possess when pricing digital innovations. Based on five case studies, including 37 interviews with key decision makers involved in the pricing process, we found that pricing of digital innovations can be conceptualized as an entrepreneurial process in which the pricing capabilities are developed based on the resources at hand. In this view, the pricing model is adjusted through negotiations with customers as an iterative process. Our findings contribute to the IS literature by integrating insights from $R B V, D R B V$, and entrepreneurship theories to the pricing process of digital innovations.
\end{abstract}

\section{Introduction}

In the field of information systems (IS), revolutionary changes have occurred in the last decades in areas such as digitalization, servitization, and the emergence of cloud computing. These changes related to knowledge systems and innovations have radically shaped industry structures, ecosystems, and business models and have consequently challenged old pricing models in the field $[1,2,3]$. Thus, research into pricing of digital services has grown significantly during the last decades. Overall, we have extensive knowledge on the different pricing aspects firms may consider $[4,5,6]$ and the factors shaping the decision between different revenue models $[1,2,3]$. However, we have a meager understanding of the resources and capabilities that are needed for pricing in this new landscape. Therefore, in this study, we are especially interested in resources and

\footnotetext{
${ }^{1}$ In this study, we define digital innovations as "a range of innovation outcomes, such as new products, platforms and services" ([11], p. 224).
}

capabilities that management teams, also known as digital entrepreneurs (cf. [9, 10]), should have when they set a price for digital innovations ${ }^{1}$ that they develop and market.

A firm's capability to set appropriate prices for its products or services will largely determinate its success or failure in the market $[12,13,14]$. Hence, to survive in the market competition, entrepreneurs ${ }^{2}$ should develop resources and capabilities that enable them to find the most profitable price that customers are willing to pay $[4,5]$. In this context, we apply two different streams of theories to get a more comprehensive understanding of the topic. First, we use entrepreneurial theories, namely, effectuation and causation logics [17, 18], to better understand the actions taken by entrepreneurs toward a viable pricing model. Secondly, we apply a resource-based view (RBV) to better understand the resources needed for a pricing decision (e.g., [19]). RBV conceptualizes a firm as a bundle of assets that are valuable, rare, inimitable, and nonsubstitutable [20, 21, 22]. These resources form competitive advantages over other firms in the market. Closely related to $\mathrm{RBV}$, we employ the dynamic resource-based view (DRBV) [23] of the firm. In DRBV, entrepreneurs utilize different resources and develop capabilities through searching for viable alternatives in the market [23]. Based on these theoretical insights, we can theorize that firms' pricing capability requires the presence of skillful entrepreneurs and their ability to develop specific pricing-related routines and assets (cf. [23, 24]). Hence, the pricing decision might be largely based on the resources and activities that entrepreneurs possess.

To increase our understanding of the conundrum discussed above, this study seeks to answer the following research question: What kind of activities and resources are needed for the pricing of digital innovations? Due to the lack of an explicit understanding of the phenomenon, we conducted 37 indepth interviews with key decision-makers of five firms

\footnotetext{
${ }^{2}$ We define entrepreneur(s) as an actor or group of actors who control firm's resources, orchestrate the pricing process and makes the pricing decision.
} 
on the pricing practices of digital services through the theoretical lenses of RBV, DRBV, and entrepreneurship theories.

The structure of the article is as follows. In the next section, we give an overview on the theories and pricing literature of digital innovations. Then, the research methodology is outlined. Thereafter, the findings of the study are presented, followed by a discussion on the findings in relation to the previous literature. Finally, in the last section, the conclusions of the study are described.

\section{Literature review}

\subsection{Theoretical background}

In this study, we conceptualize the pricing as an entrepreneurial process where entrepreneurs act and react to the changes in the market environment when they search for new pricing opportunities based on available resources. Entrepreneurship theories can be applied to increase our understanding of how pricing models emerge as entrepreneurial opportunities and of the conditions in which such opportunities are realized [25]. We apply these entrepreneurial theories, namely, effectuation and causation logics $[17,18]$, to seek to reveal how entrepreneurs "effectuate" a successful combination of different resources to set price for their digital services. These theories can be used to explain the pricing process as an outcome of entrepreneurial perception, imagination, and action where entrepreneurs search for the most sustainable pricing model in the interaction with partners, stakeholders, and customers (cf. [18, 26]). That is, to "pivot" [63] a suitable pricing model, entrepreneurs must learn from past experiences, customers' reactions, stakeholders' advice, and so on. Therefore, entrepreneurs have to consider the different options available and base the actions on imagination and the existing knowledge, as the most profitable pricing can be rarely known in advance. As a result of the uncertainty, entrepreneurs cannot build reliable causal attributions and predict which sequences of actions are more likely to provide a successful pricing model.

The RBV conceptualizes the firm as a bundle of resources that generate value for the organization [20, $21,22]$. It suggests that firms should acquire, control, and get access to resources that are valuable, rare, inimitable, and non-substitutable [20, 21, 22] to acquire competitive advantages in the market. Based on the $\mathrm{RBV}$, the pricing capability of a firm can be seen as organizational capability, manifested through the pricing process that integrates and combines different resources and capabilities [19]. An organizational capability is "a high-level routine (or collection of routines) that, together with its implementing input flows, confers upon an organization's management a set of decision options for producing significant outputs of a particular" ([27], p.983). That is, organizational capabilities include both routines that perform specific tasks and activities that coordinate these necessary tasks for a well-defined goal [23]. However, to better understand the evolution of capabilities needed for pricing, we apply DRBV, which is closely related to RBV. It provides an understanding about how capabilities evolve through founding, development, and maturity phases as a source of heterogeneity of organization capabilities [23]. Based on this, the development of a firm's pricing capability relies on the presence of skilful entrepreneurs and their ability to develop specific pricing-related routines and assets (cf. $[23,24])$. In more detail, pricing can be seen from a microfoundational perspective; that is, as a decision made by entrepreneurs with different traits and behaviors that affect organizational outcomes [12]. However, from an organizational point of view, besides investing in human resources, the organizational processes and routines have to be developed as well [19, 24]. Firms also need to invest in tangible resources, such as IT systems and other tools [19]. Therefore, the key pricing resources can be categorized into skills and competences, relational resources, and tangible resources [19].

\subsection{Pricing of digital innovations}

Pricing of digital innovations has several aspects that make the pricing models non-transparent and difficult to compare [28]. First, pricing decisions are largely based on the information that entrepreneurs have at the moment of the price formation [6, 29]. Based on this information, entrepreneurs might apply cost-based, value-based, competition-oriented, performance-based pricing, or some combination of these [30, 31, 32, 33, 34]. First, even though the cost aspects cannot be fully neglected when pricing digital innovations, due to their special cost structure, their pricing cannot be based solely on cost because the cost determines the volume of profitable operations and not the price $[35,36]$. In contrast, variable cost factors (e.g., hosting and maintenance costs and costs related to improving the quality of service) are often taken into account in pricing digital innovations [6]. Secondly, in value-based pricing, entrepreneurs take into consideration the value that customers perceive when using the innovation [21, 22 , 19]. Thirdly, in competition-oriented pricing, competitive forces, such as the bargaining power of customers and providers, influence the entrepreneurs' pricing decision [1, 39]. Finally, in performance-based 
pricing, the risks regarding the benefits that the service brings are shared between customers and suppliers, and the customer pays only after the benefits have been realized [40]. various types, such as software, IT services, or human services. From an entrepreneur's perspective, the benefits of price bundling can vary. First, it may be used for price discrimination, especially when the

Table 1. Overview of the case firms

\begin{tabular}{|c|c|c|c|c|}
\hline Firm & $\begin{array}{c}\text { Year of } \\
\text { establishment }\end{array}$ & $\begin{array}{l}\text { Number of } \\
\text { employees }\end{array}$ & Target customers & $\begin{array}{l}\text { Number of } \\
\text { interviews }\end{array}$ \\
\hline $\mathrm{A}$ & 1996 & 25 & Banks & 9 \\
\hline $\mathrm{B}$ & 2012 & 20 & Diverse sectors & 2 \\
\hline $\mathrm{C}$ & 2011 & 4 & Museums & 5 \\
\hline $\mathrm{D}$ & 1998 & 30 & $\begin{array}{l}\text { Telecom operators, component manufacturers, } \\
\text { and service providers for telecom networks }\end{array}$ & 8 \\
\hline $\mathrm{E}$ & 2006 & 40 & Furniture chains and furniture manufacturers & 13 \\
\hline Total & & & & 37 \\
\hline
\end{tabular}

Another important aspect of pricing is related to the length of time that the user can use an innovation $[6,29]$. The traditional revenue model that has been used in software-based digital innovations is software licensing. This refers to the model in which customers buy a perpetual license for software that gives them the rights to use the software on a specific number of computers or processors for a certain period of time or with unlimited usage rights $[38,41,42]$. However, due to the emergence of digitalization and cloud computing, these innovations are increasingly priced by using subscription-based pricing (i.e. renting) or usage-based pricing. In these pricing models, customers buy the rights to use the innovation for a certain time period (subscription based), or customers are charged based on the actual usage of the software $[7,8,43]$. One of the main advantages of these models is that it makes the innovation more attractive for customers due to the lower inception costs [1].

Entrepreneurs may also specialize these pricing models further by using price discrimination, where the same innovation is offered to different customer segments at different prices [44]. This strategy is especially beneficial in the case of low variable costs, since entrepreneurs may reach customer segments with a lower willingness to pay [6]. In the literature, second degree price discrimination is also referred as versioning, where entrepreneurs offer different productprice combinations to its customers [45]. Even though entrepreneurs may achieve a revenue increase due to second degree price discrimination [46], when the number of versions is too high, it may be confusing for customers and may increase variable costs for entrepreneurs [47].

Pricing models might also differ in the scope of the offer that represents its granularity [6, 29]. In an offer, each unit can be priced separately, or in the case of price bundling, several items may be bound together with a predetermined price [6]. Items in the bundle can be of willingness to pay is difficult to separately forecast for each unit [47]. Secondly, bundling allows a greater distribution of different units that may cause an increase in revenues due to network externalities [6]. Finally, cost savings may be achieved due to a decrease in transaction costs of billing and delivery [47].

\section{Methodology}

The aim of this study was to investigate a complex phenomenon - pricing of digital innovations - in its real-life context, where the pricing decisions, resources, and activities play a critical role in a firm's survival. Furthermore, we sought an in-depth understanding of the behavioral foundations of the pricing decision made by entrepreneurs within the firm. To gain an in-depth understanding of this phenomenon, we applied an exploratory case study method [48]. This method was chosen because it is capable of encompassing empirically rich and detailed data related to a complex phenomenon that is based on human actions and decision making $[49,50,51]$. The qualitative case study method helped us to capture the possible cause-andeffect relationships [52, 53, 54, 55] where entrepreneurs sought, developed, and combined different resources and activities to develop their pricing capabilities for a pricing decision.

\subsection{Data selection}

The research setting of the study consisted of five case firms that develop and market digital innovations. We selected the case firms by using purposeful theoretical sampling, as recommended by Eisenhardt [53] and by Eisenhardt and Graebner [54]. We applied multiple criteria for case firm selection. First, we selected case firms that all developed digital innovations for different target industries. Hence, we aimed to 
include "polar types" of research sites. This was important because in studies having only a small sample of firms, it is recommended that a wide variety of firms be included in the sample $[53,55]$. Secondly, to expand the variety of the firms, we selected both recently established and relatively old firms. Thirdly, all the firms were relatively small and led by a group of entrepreneurs who were closely involved in the pricing decisions. Lastly, based on recommendations by Stake [56], we selected firms for which we had good access and had established personal contacts. This increased the firms' willingness to participate in the study and to share, in many cases, confidential information related to their pricing decisions. Table 1 gives an overview of the case firms.

\subsection{Data collection}

In the data collection, we used multiple sources of information. The main form of data collection was indepth interviews. The initial interviews were fairly unstructured and focused on collecting general information on the firm, its products and services, customers, business models, and so forth. In the second and subsequent interview(s), more detailed questions about the pricing were asked based on the information gathered in the previous interview(s). We conducted interviews with various employees of the case firms that contributed to the firm's pricing activities. However, the main sources of the information were entrepreneurs; that is, the founding team of the firm. This team included two to four persons. Altogether, this study included 37 interviews. The length of the interviews varied between 45 and 60 minutes, and all of them were recorded and transcribed. In addition to face-to-face meetings, data were gathered through emails and phone calls. For the secondary data, we used the case firms' web pages, brochures, and press releases. This data was mainly used to validate the collected interview data.

\subsection{Data analysis}

In the data analysis phase, we utilized content analysis. The case data analysis consisted of three concurrent flows of activity [57]: (i) data reduction, (ii) data displays, and (iii) conclusion-drawing/verification. In the (i) data reduction phase, the data were given focus and simplified through the compilation of a detailed case history of each firm. This is in line with Pettigrew (1990), who suggested that organizing incoherent aspects in chronological order is an important step in understanding the casual links between events. Then, on

Table 2. Overview of the case firms' pricing strategies

\begin{tabular}{|c|c|c|c|c|}
\hline Firm & Digital innovation & Pricing models & Pricing factor & $\begin{array}{l}\text { The basis of pricing (cost-, } \\
\text { value-, competition, or } \\
\text { performance) }\end{array}$ \\
\hline $\bar{A}$ & $\begin{array}{l}\text { Real-time } \\
\text { intelligence } \\
\text { solutions for banks }\end{array}$ & $\begin{array}{l}\text { Initial project fee and } \\
\text { subscription-based revenue } \\
\text { model }\end{array}$ & $\begin{array}{l}\text { The number of } \\
\text { employees on the } \\
\text { asset and liability } \\
\text { management team }\end{array}$ & $\begin{array}{l}\text { Value-based pricing; however, } \\
\text { the cost and competitors' } \\
\text { prices are also considered }\end{array}$ \\
\hline B & $\begin{array}{l}\text { Digital platform for } \\
\text { indoor positioning } \\
\text { and for location- } \\
\text { based services }\end{array}$ & $\begin{array}{l}\text { Different revenue model for } \\
\text { different verticals, such as the } \\
\text { license-based revenue model, } \\
\text { subscription-based revenue } \\
\text { model, and revenue-share } \\
\text { model }\end{array}$ & $\begin{array}{l}\text { Monthly active users, } \\
\text { location-based } \\
\text { pricing, number of } \\
\text { transactions }\end{array}$ & $\begin{array}{l}\text { Value-based pricing and in the } \\
\text { case of the revenue-share } \\
\text { model, performance-based } \\
\text { pricing }\end{array}$ \\
\hline $\mathrm{C}$ & $\begin{array}{l}\text { Digital platform to } \\
\text { develop media } \\
\text { guides }\end{array}$ & $\begin{array}{l}\text { Initial project fee and } \\
\text { subscription-based revenue } \\
\text { model }\end{array}$ & $\begin{array}{l}\text { Number of annual } \\
\text { visitors }\end{array}$ & $\begin{array}{l}\text { The price is set based on all the } \\
\text { three factors (competitors' } \\
\text { prices, costs, and the } \\
\text { customers' ability to pay) }\end{array}$ \\
\hline $\mathrm{D}$ & $\begin{array}{l}\text { Planning and } \\
\text { optimization } \\
\text { software platform } \\
\text { for telecom } \\
\text { operators }\end{array}$ & $\begin{array}{l}\text { Subscription-based pricing } \\
\text { model }\end{array}$ & Number of users & $\begin{array}{l}\text { The price is set based on costs } \\
\text { and risks, competitors' prices, } \\
\text { and customers' perceived } \\
\text { benefits; the most influential } \\
\text { factor is customer-specific }\end{array}$ \\
\hline $\mathrm{E}$ & $\begin{array}{l}\text { Real-time } \\
\text { visualization } \\
\text { platform }\end{array}$ & $\begin{array}{l}\text { Initial project fee and } \\
\text { subscription-based revenue } \\
\text { model and usage-dependent } \\
\text { hosting pricing component }\end{array}$ & $\begin{array}{l}\text { Number of customers' } \\
\text { products, number of } \\
\text { modules included, } \\
\text { location of the } \\
\text { customer }\end{array}$ & Value-based pricing \\
\hline
\end{tabular}


the basis of interviews and other material collected from the case firms, we used tables to identify and categorize the unique patterns of each case under subtopics derived from the research question. These patterns were related to the following subtopics: i) Pricing model, ii) Pricing process, and iii) Resources related to pricing. In addition, we used checklists and event listings to identify the critical factors (e.g. new pricing criteria) related to the phenomena encountered [57]. In (ii) the data display phase, we arranged the relevant data drawn from the findings of the earlier phase into new tables. In (iii) the conclusion drawing and verification phase, we first concentrated on identifying the aspects that appeared to have significance for this study. At this stage, we noticed regularities, patterns, explanations, and causalities related to the phenomena. After conclusion drawing, we verified the results with interviewees and carried out discussions to avoid misunderstandings.

\section{Findings}

\subsection{Overview of the case firms' pricing models}

Even though the nature of the digital innovations has varied greatly among the case firms, all the firms used the subscription-based pricing model. This pricing model was complemented with a variety of aspects that diverged based on the factors that entrepreneurs applied to set the subscription fee. These factors were related to the functionalities of the service (firms B and E) and/or the size/number of the customers (firms A, B, C, and D). Besides the subscription fee, firms A, C, and E charged a one-time initial project fee for scoping the customers' requirements, customization, deployment, and integration. This fee typically varied based on the workload required. In addition, all the firms (except of Firm C) bundled different features with different levels of the digital innovation and offered these feature-price packages to their customers. Further, Firm E had different prices for its service for different geographies where the service was used. Table 2 provides an overview of the case firms' pricing strategies.

Overall, the case firms mainly based their prices on the customers' perceived value of the solution. For this, entrepreneurs have to understand the value that their service brings to the customers. When entrepreneurs converted the value-based pricing strategy to a pricing model at the operational level, they had to identify the factors that the customers' perceived value depends on. These factors were not always easy to find and operationalize - the task needs understanding of both the firm's value proposition and the customers' business. The entrepreneurs in the case firms revealed that defining the most influential pricing base was not always straightforward. The entrepreneurs had to consider several variables, such as production costs, risks, competitors' prices, and customers' value.

Generally, the competitors' influence on the prices was rather small. There were either very few competitors, or the competitors used very different technology. We found that the competitors might also affect the prices in an unusual way. For example, Firm A had very large customers whose expenditures were of a different scale compared to the prices demanded by Firm A. As a result, Firm A had to increase its prices to make its product "sound" more reliable. In addition, the firms also had to estimate the customer's ability and willingness to pay.

\subsection{Pricing process}

Overall, pricing decisions were made within crossfunctional teams including different sources of expertise. The team members commonly included the founding team (entrepreneurs) with positions such as CEO and CTO. In addition, these teams were expanded with sales manager(s) and customer relationship manager(s) that had different knowledge and skills. Thus, a whole team was needed due to the heterogeneity in the needed competences and skills. In this team, most of the decision makers were also the board members of the firm. Further, Firm E involved representatives of its partners (distributors, foreign vendors, etc.) in the pricing process because these partners had critical knowledge of the pricing in specific foreign markets. These teams applied very innovative pricing processes without any strict or formal rules. Still, the pricing was not an ad-hoc activity. It was rather a result of a flexible strategy involving communication with customers and among the board members of the firms to define the final price.

The case findings revealed two iterative activities in the pricing process of digital innovations. These activities were i) pricing model development and ii) negotiation. The first activity, the development of a pricing model, included all the activities that led to the development of a pricing model at the operational level, such as brainstorming sessions by the decision makers of the firm with different skills, cost and risk estimation, and analyses of target customers' willingness to pay and perceived values. Besides, the different pricing aspects in the pricing model had to be quantified and converted into one monetary value in each customer case.

The second activity was related to the negotiations between entrepreneurs and customers to clarify customers' requirements for the innovation and to calculate how these requirements impact the final price. The case firms differed in the role that negotiation 
played in pricing their innovations. First, the case firms $\mathrm{A}$ and $\mathrm{C}$ developed their pricing logic once, and after that, they used the predefined price list during the negotiations with new customers. During these negotiations, the customers had rather limited influence on the price. However, the case firms D and E decided the final price case by case, and the customers' feedback and viewpoint had an impact on the pricing model as well as on the final price. Finally, Firm B focused mostly on the pricing model development activity due to the heterogeneity of the target industries and differences in customers' perceived benefits.

In many cases, the development of a tentative pricing model was the most challenging task because a firm was just established or they were launching a totally new innovation. In the beginning of this process, firms $\mathrm{A}$ and $\mathrm{C}$ developed a tentative pricing model at the early phase of their history. This so-called "price list" included the price of the basic service and the price of the additional modules and functionalities. The price list was used to negotiate with new customers as it made it easier to show customers how different functionalities impact the final price. However, the list included a lot of flexibility and gave room to negotiate with alternative solutions with customers. Entrepreneurs in the other firms (B, D, and E) applied a pricing model in which they set the price on a more individual basis for each new customer. After developing a tentative pricing logic, the pricing models had to be continuously adjusted and refined. That is, changes to the pricing models were necessary for ongoing changes in high-velocity digital environment. First, changes in customers' needs induced the development of new functionalities or services that had to be separately priced or bound to already-existing feature packages. Second, when entrepreneurs expanded their operations to new industries, they encountered a need to adjust or replace outdated pricing models. Finally, in some cases, new regulations and new laws required changes to the service that necessitated revisions to the existing pricing model.

Because of the high-volatility market of the digital innovations, the pricing capability of the case firms also evolved through trial and error as well as from learning by doing strategies. For example, the revenues of Firm $\mathrm{E}$ in its domestic market was too low because it did not dare to set high enough prices for its first customers, and based on the contract, it has not been able to increase these prices to a suitable level even today. Then, the firm expanded its business to foreign markets with higher prices as it learned from mistakes in the domestic market, and today it is able to set appropriate prices when entering new countries. The CEO of Firm E explained the change in the pricing strategy in foreign markets as follows:
We try to find the maximum price that a customer is willing to pay. When we started, we were just happy if someone paid something. Our first license fees in Finland were around ( $x$ ) Euros. It was money, and we were happy. However, later we realized that our revenue in Finland was too small. Thereafter we expanded to Sweden; we added simply some digits in the end of the price. We checked whether it goes through ... and it went through.

As another example, the entrepreneurs from Firm B had to develop new and more flexible pricing models in addition to the traditional license model. This was because the previous pricing logic was not proportional to the customers' benefits in some of the target vertical industries.

\subsection{Resources needed for pricing}

The resources that the case firms used for pricing can be categorized into three groups: i) skills and competences, ii) relational resources, and iii) tangible resources. Further, the first group "skills and competencies" included four different resources: i) technical skills and knowledge, ii) negotiations skills, iii) market knowledge, and iv) analytical skills. Related to technical skills and knowledge, entrepreneurs acknowledged that the pricing of digital innovations is a complex activity that cannot be done without profound technological skills. Decision makers have to understand the technical details of the value of the innovation to be able to detect its potential and to identify new possible customers and customer segments. Besides, technical skills are needed because for every new customer or new functionality requirement, the needed work amount has to be estimated, the risks have to be identified, and the overall costs have to be calculated. Thus, one person with the firm's specific technical knowledge has to be involved in pricing. Secondly, case firms acknowledge the important role of the negotiation skill. As discussed above, most of the entrepreneurs of the case firms based their pricing decisions on the created value rather than on the cost or competitors' prices. That is, the uniqueness of the value proposition of the firms brought great value to the customers, and it had to be captured through suitable prices. Thus, the pricing team needs exceptional negotiation skills and a "poker eye" to close deals with the maximum price that the customer is willing to pay. Thirdly, the market knowledge is an important competence that encompasses the knowledge of the target industry, the competitors' value propositions, and in some cases, the understanding of a foreign country and its culture. Decision makers should react fast to market changes and identify new customer 
segments. The importance of the market knowledge was explained by the CEO of Firm $\mathrm{C}$ as follows:

One of the most important skills is the market sensitivity. You have to know the market. Even if you have a very good product, if the market expectations are different or the customers' ability to pay is different, then you can't make a deal ... Knowing the market, understanding it, that is essential.

Fourth, besides understanding the market and the value created, analytical skills are needed for value quantification. For example, Firm $\mathrm{E}$ involved one additional employee in the pricing process who was able to quantify the value that the firm's value proposition brought for the customers. For this capability, system thinking, a profound understanding of the customer business and identifying the value proposition's benefits was needed.

The group Relational resources were related to business-to-business networks (such as customers, possible customers, partners, and other actors in the ecosystems). Relational resources formed one of the most important sources for information from the customers. For example, for Firm C, the direct feedback from the potential customers about their willingness to pay and the benefits that the service would bring to them was a key determinant in the pricing decision. However, Firm B built an ecosystem around its technology, and it had an opportunity to get feedback not only directly from its customers but also from the possible customers and other partners of the ecosystem. Firm B and E involved the partner firms in pricing especially because of their target industry knowledge or the market knowledge in foreign countries. The CEO of Firm B explained this as follows:

The price comes from the value that the service brings to the customers, but this is where the partner firms come into the picture, who really do the work. We do not necessarily understand all the verticals when we have so many.

The third group of resources included tangible resources, which were also an important source of the pricing decision. First, IS infrastructure was vital for all the case firms in most of the tasks of the pricing process. That is, entrepreneurs used different IT systems and software tools to collect information and analyze the data, to communicate, and most importantly, to develop the firms' own pricing tool. Second, in pricing model development, as well as when quantifying the pricing model into price, the case firms overviewed the market data through public forecasts and reports of the target market. Finally, the firms' budget and business plans were needed to ensure that the prices corresponded to the firms' strategy. It should be noted that all the case firms accentuated the importance of transparency and proper documentation in pricing. That is, the customers needed to understand the different factors and their effect on the overall price to make an informed decision.

\section{Discussion}

In general, the case firms applied typical pricing models for digital innovations. Their pricing was based on a subscription fee that was largely dependent on the value of the digital innovation for the customers. This finding is in line with earlier studies focusing on different types of digital innovations [35, 37, 38]. However, in this study, we go beyond these general findings on different pricing models and strategies to reveal the actions and resources that entrepreneurs need when pricing digital innovations.

The findings adduce that entrepreneurial actions and reactions had important roles when entrepreneurs were looking for a correct pricing model for their digital innovations. It became evident that the entrepreneurs were not able to estimate the right pricing model in advance. In the beginning of the pricing process, they used their existing means [17, 18]; that is, the resources they had available within the firm. Here, the heterogeneity of the team and their possible contacts played a critical role. Based on these resources at hand, the entrepreneurs developed calculations of the value that the innovation brought to the potential customers and developed tentative pricing model based on these estimations. However, the process evolved through trial and error, and the entrepreneurs learned from their mistakes and through communication with customers and partners (cf. [18, 26]). This made their pricing model flexible compared to other industries (e.g., [19, 58]). That is, decisions on pricing do not include official procedures, such as setting and approving the pricing strategy.

In line with earlier works from more traditional industries (e.g., [19, 24, 40, 58, 59]), we found that the following three different types of resources have important role in pricing: i) skills and competences, ii) relational resources, and iii) tangible resources. However, even though the resources found in earlier research can be categorized in the same way, the found key pricing resources differed in their importance due to the digital market conditions and special characteristics of the digital innovations. That is, the firms covered in this study operate in high-velocity environments, where information is often unavailable, inaccurate, or obsolete due to the fast changes in demand, technology, competitors, or regulations [60]. This makes the pricing 
of digital innovations non-inimitable (cf. [20, 21, 22]) and distinguishes digital innovation providers from other firms. That is, the pricing model cannot be copied from other firms or competitors. Instead, pricing has to be developed inside the firm by combining different resources that are developed over the time through interaction between entrepreneurs, customers and other actors in the market.

We found two different activities (development of the pricing model and negotiation) that entrepreneurs followed iteratively when pricing the digital innovation. These activities lead to developing a tentative pricing model, that had to be adjusted and refined due to internal (e.g., new functionalities) and external (e.g., market changes, new customers, and new target verticals) reasons. Thus, these phases of the pricing process followed somewhat the three phases (founding, development, and maturity) in DRBV [23]. However, it seems that due to the high-velocity environment, it becomes difficult or impossible for entrepreneurs to reach the maturity phase, as the need for changes in the case of digital innovations is ongoing (cf. [11]).

\section{Conclusions}

This multi-case study makes several important contributions to the previous literature and theory development in the context of digital innovations. In summary, our findings reveal that i) the pricing of digital innovations can be conceptualized as an entrepreneurial process in which the pricing capabilities are developed based on the resources at hand; ii) for successful pricing, entrepreneurs need skills and competences, relational resources, and tangible resources; and iii) the dynamics of the pricing model includes the following activities: the development of the pricing model and negotiation with the customers.

In the first place, our findings contribute to digital innovation and the digital entrepreneurship literature $[11,25,61]$ in the context of pricing. It reveals how the pricing of digital innovations evolves as an entrepreneurial process (cf. [17, 18]) that is closely related to the resources that entrepreneurs possess. This entrepreneurship aspect has been largely absent in the previous pricing literature on digital innovations $[14,15$, $16,17,18,35]$.

Secondly, we contribute to entrepreneurship theories $[17,18]$, RBV [20, 21, 22], and DRBV [23] in the context of digital innovations pricing. Our study increases the understanding on how the entrepreneurs' pricing decisions are based on existing resources and how entrepreneurs develop pricing capabilities through different activities in the market. This puts forward the previous work on pricing in the context of RBV [19] [62] and extends it toward a more dynamic process [23].

Overall, this research is a first step in exploring the pricing of digital innovations in an entrepreneurship, RBV, and DRBV context. Due to the methodological circumstances, the findings might not be generalized to all possible digital innovations. However, research would greatly benefit from a longitudinal study of the evolution of pricing capabilities. Further, by integrating wider disparity of cases would validate and extend the findings of this study. Finally, quantitative studies are needed to investigate how different pricing-related decisions affect the firms' income and further performance.

\section{References}

[1] A. Ojala, 'Adjusting Software Revenue and Pricing Strategies in the Era of Cloud Computing', J. Syst. Softw., vol. 122, pp. 40-51, 2016.

[2] D. S. Evans and R. Schmalensee, Matchmakers: The new economics of multisided platforms. Harvard Business Review Press, 2016.

[3] G. G. Parker, M. W. Van Alstyne, and S. P. Choudary, Platform Revolution: How Networked Markets Are Transforming the Economyand How to Make Them Work for You. WW Norton \& Company, 2016.

[4] H. K. Bhargava and V. Choudhary, 'Information goods and vertical differentiation', J. Manag. Inf. Syst., vol. 18, no. 2, pp. 89-106, 2001.

[5] G. Laatikainen, A. Ojala, and O. Mazhelis, 'Cloud services pricing models', in International Conference of Software Business, 2013, pp. 117-129.

[6] S. Lehmann and P. Buxmann, 'Pricing Strategies of Software Vendors', Bus. Inf. Syst. Eng., vol. 1, no. 6, pp. 452-462, 2009.

[7] A. Ojala, 'Software Renting in the Era of Cloud Computing', in Cloud Computing (CLOUD), 2012 IEEE 5th International Conference on, 2012, pp. 662669.

[8] A. Ojala, 'Software-as-a-Service Revenue Models', IT Prof., vol. 15, no. 3, pp. 54-59, 2013.

[9] E. Davidson and E. Vaast, 'Digital entrepreneurship and its sociomaterial enactment', in System Sciences (HICSS), 2010 43rd Hawaii International Conference on, 2010, pp. 1-10.

[10] S. Nambisan, 'Digital entrepreneurship: Toward a digital technology perspective of entrepreneurship', Entrep. Theory Pract., vol. 41, no. 6, pp. 1029-1055, 2017.

[11] S. Nambisan, K. Lyytinen, A. Majchrzak, and M. Song, 'Digital innovation management: Reinventing innovation management research in a digital world.', Mis Q., vol. 41, no. 1, 2017.

[12] A. Hinterhuber and S. M. Liozu, 'The microfoundations of pricing', J. Bus. Res., vol. 76, no. Supplement C, pp. 159-162, 2017. 
[13] T. T. Nagle and R. K. Holden, The strategy and tactics of pricing: A guide to profitable decision making. Prentice Hall Englewood Cliffs, NJ, 2002.

[14] N. F. Piercy, D. W. Cravens, and N. Lane, 'Thinking strategically about pricing decisions', J. Bus. Strategy, vol. 31 , no. 5 , pp. $38-48,2010$.

[15] M. Johansson, N. Hallberg, A. Hinterhuber, M. Zbaracki, and S. Liozu, 'Pricing strategies and pricing capabilities', J. Revenue Pricing Manag., vol. 11, no. 1, pp. 4-11, 2012.

[16] R. Makadok and J. B. Barney, 'Strategic Factor Market Intelligence: An Application of Information Economics to Strategy Formulation and Competitor Intelligence', Manag. Sci., vol. 47, no. 12, pp. 16211638, 2001.

[17] S. D. Sarasvathy, Effectuation: Elements of entrepreneurial expertise. Edward Elgar Publishing, 2009.

[18] S. D. Sarasvathy, 'Causation and effectuation: Toward a theoretical shift from economic inevitability to entrepreneurial contingency', Acad. Manage. Rev., vol. 26, no. 2, pp. 243-263, 2001.

[19] S. Dutta, M. J. Zbaracki, and M. Bergen, 'Pricing process as a capability: a resource-based perspective', Strateg. Manag. J., vol. 24, no. 7, pp. 615-630, 2003.

[20] J. Barney, 'Firm resources and sustained competitive advantage', J. Manag., vol. 17, no. 1, pp. 99-120, 1991.

[21] B. Wernerfelt, 'From critical resources to corporate strategy', J. Gen. Manag., vol. 14, no. 3, pp. 4-12, 1989.

[22] B. Wernerfelt, 'A resource-based view of the firm', Strateg. Manag. J., vol. 5, no. 2, pp. 171-180, 1984.

[23] C. E. Helfat and M. A. Peteraf, 'The dynamic resourcebased view: Capability lifecycles', Strateg. Manag. J., vol. 24, no. 10, pp. 997-1010, 2003.

[24] N. L. Hallberg, 'The micro-foundations of pricing strategy in industrial markets: A case study in the European packaging industry', J. Bus. Res., vol. 76, pp. 179-188, 2017.

[25] S. Nambisan, 'Digital entrepreneurship: Toward a digital technology perspective of entrepreneurship', Entrep. Theory Pract., vol. 41, no. 6, pp. 1029-1055, 2017.

[26] S. A. Alvarez and J. B. Barney, 'Discovery and creation: Alternative theories of entrepreneurial action', Strateg. Entrep. J., vol. 1, no. 1-2, pp. 11-26, 2007.

[27] S. G. Winter, 'The Satisficing Principle in Capability Learning', Strateg. Manag. J., vol. 21, no. 10/11, pp. 981-996, 2000.

[28] M. A. Cusumano, 'The changing labyrinth of software pricing', Commun.ACM, vol. 50, no. 7, pp. 19-22, 2007.

[29] E. Iveroth, A. Westelius, C.-J. Petri, N.-G. Olve, M. Cöster, and F. Nilsson, 'How to differentiate by price: Proposal for a five-dimensional model', Eur. Manag. J., vol. 31, no. 2, pp. 109-123, 2013.

[30] S. Bonnemeier, F. Burianek, and R. Reichwald, 'Revenue models for integrated customer solutions: Concept and organizational implementation', $J$.
Revenue Pricing Manag., vol. 9, no. 3, pp. 228-238, 2010.

[31] R. Harmon, D. Raffo, and S. Faulk, 'Value-based pricing for new software products: strategy insights for developers', in Proc. Portland Internat. Conf. on Management of Eng. and Technol. (PICMET'04) (Seoul, Kor., 2004), 2005.

[32] A. Hinterhuber, 'Towards value-based pricing: An integrative framework for decision making', Ind. Mark. Manag., vol. 33, no. 8, pp. 765-778, 2004.

[33] D. Shipley and D. Jobber, 'Integrative Pricing via the Pricing Wheel', Ind. Mark. Manag., vol. 30, no. 3, pp. 301-314, 2001.

[34] P. Töytäri, J. Keränen, and R. Rajala, 'Barriers to implementing value-based pricing in industrial markets: A micro-foundations perspective', J. Bus. Res., vol. 76, pp. 237-246, 2017.

[35] A. W. Baur, A. C. Genova, J. Bühler, and M. Bick, 'Customer is King? A Framework to Shift from Costto Value-Based Pricing in Software as a Service: The Case of Business Intelligence Software', in Digital Services and Information Intelligence, pp. 1-13, 2014.

[36] P. Töytäri, R. Rajala, and T. B. Alejandro, 'Organizational and institutional barriers to valuebased pricing in industrial relationships', Ind. Mark. Manag., vol. 47, pp. 53-64, 2015.

[37] R. Harmon, H. Demirkan, B. Hefley, and N. Auseklis, 'Pricing Strategies for Information Technology Services: A Value-Based Approach', in System Sciences, 2009. HICSS '09. 42nd Hawaii International Conference on, 2009, pp. 1-10.

[38] N. Bontis and H. Chung, 'The evolution of software pricing: from box licenses to application service provider models', Internet Res., vol. 10, no. 3, pp. 246255, 2000

[39] M. E. Porter, Competitive Strategy: Techniques for Analyzing Industries and Competitors. Free Press, New York, 1980.

[40] A. Hinterhuber, 'Value quantification capabilities in industrial markets', J. Bus. Res., vol. 76, pp. 163-178, 2017.

[41] M. A. Cusumano, 'Cloud computing and SaaS as new computing platforms', Commun. ACM, vol. 53, no. 4, pp. 27-29, 2010.

[42] D. Ferrante, 'Software Licensing Models: What's Out There?', IT Prof., vol. 8, no. 6, pp. 24-29, 2006.

[43] V. Choudhary, 'Comparison of Software Quality Under Perpetual Licensing and Software as a Service', J Manage Inf Syst, vol. 24, no. 2, pp. 141-165, 2007.

[44] V. Choudhary, A. Ghose, T. Mukhopadhyay, and U. Rajan, 'Personalized pricing and quality differentiation', Manag. Sci., vol. 51, no. 7, pp. 11201130, 2005.

[45] H. R. Varian, 'Versioning information goods', Univ. Calif. Berkeley, 1997.

[46] H. K. Bhargava and V. Choudhary, 'Second-degree price discrimination for information goods under nonlinear utility functions', in System Sciences, 2001. Proceedings of the 34th Annual Hawaii International Conference on System Science, 2001. 
[47] S. Viswanathan and G. Anandalingam, 'Pricing strategies for information goods', Sadhana, vol. 30, no. 2, pp. 257-274, 2005.

[48] R. K. Yin, Case study research: Design and methods, vol. 5. sage, 2003.

[49] I. Benbasat, D. K. Goldstein, and M. Mead, 'The Case Research Strategy in Studies of Information Systems', MIS Q., vol. 11, no. 3, pp. 369-386, 1987.

[50] A. C. Edmondson and S. E. McManus, 'Methodological fit in management field research', Acad. Manage. Rev., vol. 32, no. 4, pp. 1246-1264, 2007.

[51] R. K. Yin, Case study research: Design and methods. CA: SAGE Publications, 2009.

[52] P. Darke, G. Shanks, and M. Broadbent, 'Successfully completing case study research: combining rigour, relevance and pragmatism', Inf. Syst. J., vol. 8, no. 4, pp. 273-289, 1998.

[53] K. M. Eisenhardt, 'Building theories from case study research', Acad. Manage. Rev., vol. 14, no. 4, pp. 532550, 1989.

[54] K. M. Eisenhardt and M. E. Graebner, 'Theory building from cases: Opportunities and challenges', Acad. Manage. J., vol. 50, no. 1, pp. 25-32, 2007.

[55] A. M. Pettigrew, 'Longitudinal field research on change: theory and practice', Organ. Sci., vol. 1, no. 3, pp. 267-292, 1990.

[56] R. E. Stake, 'The art of case study research', 1995.
[57] M. B. Miles and A. M. Huberman, Qualitative data analysis: An expanded sourcebook. Sage, 1994.

[58] J.-P. van der Rest, A. Roper, and X. L. Wang, 'Why is a change of company pricing policy so hard to implement?', Int. J. Hosp. Manag., vol. 69, pp. 30-40, 2018.

[59] H. Forman and J. M. Hunt, 'Managing the influence of internal and external determinants on international industrial pricing strategies', Ind. Mark. Manag., vol. 34 , no. 2, pp. 133-146, 2005.

[60] K. M. Eisenhardt and L. J. Bourgeois, 'Politics of Strategic Decision Making in High-Velocity Environments: Toward a Midrange Theory', Acad. Manage. J., vol. 31, no. 4, pp. 737-770, 1988.

[61] Y. Yoo, O. Henfridsson, and K. Lyytinen, 'Research commentary - the new organizing logic of digital innovation: an agenda for information systems research', Inf. Syst. Res., vol. 21, no. 4, pp. 724-735, 2010.

[62] S. Dutta, M. Bergen, D. Levy, M. Ritson, and M. Zbaracki, 'Pricing as a strategic capability', MIT Sloan Manag. Rev. Camb., vol. 43, no. 3, pp. 61-66, 2002.

[63] E. Ries. The Lean Startup: How Today's Entrepreneurs Use Continuous Innovation to Create Radically Successful Businesses, New York: Crown Business. 2011. 